\title{
Communication
}

(Comunicação)

\section{Evaluation of acid detergent insoluble protein as an estimator of rumen non-degradable protein in tropical grass forages}

\author{
[Avaliação da proteína insolúvel em detergente ácido como estimador da proteína \\ não degradável no rúmen para forragens tropicais]
}

\author{
R.C. Clipes $^{1}$, E. Detmann ${ }^{2,5 *}$, J.F.C. Silva ${ }^{3,5}$, R.A.M. Vieira ${ }^{3}$, L.B.M. Nunes ${ }^{4}$, F.N. Lista $^{1}$, N.J. Ponciano \\ ${ }^{1}$ Aluno de pós-graduação - UENF - Campos dos Goytacazes, RJ \\ ${ }^{2}$ Departamento de Zootecnia - UFV \\ Avenida P.H. Rolfs s/n \\ 36570-000 - Viçosa, MG \\ ${ }^{3}$ CCTA - UENF - Campos dos Goytacazes, RJ \\ ${ }^{4}$ Aluna de graduação - UENF - Campos dos Goytacazes, RJ \\ ${ }^{5}$ Bolsista do CNPq
}

The fraction of nitrogenous or protein compounds linked to the acid detergent insoluble portion of cellular wall (ADIP) has been used as a predictor of the rumen non-degradable protein by some of the main nutritional systems, such as the British System (Agricultural and Food Research Council - AFRC) and the Cornell System (Cornell Net Carbohydrate and Protein System-CNCPS), based on the assumption that this, although composed in part by amino acid components, does not have any availability for the rumen microorganisms or intestinal enzymatic digestion (Sniffen et al., 1992).

However, there are some studies which show controversies about the ADIP availability along the ruminant gastro-intestinal tract, which have shown digestion estimates substantially deviated from nullity (Van Soest, 1994; Detmann et al., 2003), implying that this fraction cannot be a reliable estimator of the non-degradable fraction of the nitrogenous compounds. Nevertheless, the effectiveness of the relationship between ADIP and the protein degradation in the rumen has been based on few evaluations with typically tropical grasses, generating a still incipient knowledge, at least in Brazil, about this concept. The objective of this study was to evaluate the rumen non-degradable nitrogenous compounds fraction, observed and predicted through the acid detergent insoluble nitrogenous compounds in tropical forages.

Ninety-six forage samples, obtained from June to December 2002 in Campos dos Goytacazes-RJ, from two rotational grazing systems formed by elephantgrass (Pennisetum purpureum Schum. Cv. Napier) (15 paddocks) and mombaça grass (Panicum maximum Jacq. Cv. Mombaca) (13 paddoks) which had occupation periods of three days and resting periods of 42 and 36 days, respectively, were used. Both systems had four grazing animals and $600 \mathrm{~m}^{2}$ for each paddock. The total sampling period was four grazing cycles in each system.

The forage samples were taken in a sequential form in each occupied paddock, being, however, the sampling moment alternated, so that at each group of three paddocks, the samples could be obtained in the third, second and first days of occupation, respectively. The forage of each

Recebido em 4 de julho de 2004

Aceito em 23 de fevereiro de 2006

* Autor para correspondência (Corresponding author)

E-mail: detmann@ufv.br 
paddock was sampled by hand plucking and esophageal extrusa. This last one was obtained by using two steers with esophageal-fistula.

The samples were immediately frozen $\left(-15^{\circ} \mathrm{C}\right)$, and afterwards dried by forced ventilation $\left(60^{\circ} \mathrm{C}\right.$ - 72 hours) and processed in a knife mill with a $1 \mathrm{~mm}$ screen sieve. Then, the samples were submitted to the sequential treatment in neutral and acid detergent (Goering and Van Soest, 1975), being the acid detergent residue evaluated for the nitrogen contents by the Kjeldhal method. The acid detergent insoluble protein (ADIP) was estimated multiplying the nitrogen contents by 6.25 .

Afterwards, about $1.5 \mathrm{~g}$ of each sample was put into nylon bags with a $50 \mu \mathrm{m}$ porosity (on the base of $20 \mathrm{mg} / \mathrm{cm}^{2}$ of bag surface), and incubated in the rumen of a steer fed a roughage: concentrate diet (70:30). After 240 hours, the bags were removed and washed in tap water up to get clean water. The samples were treated with neutral detergent (Goering and Van Soest, 1975), and the nitrogen contents were analyzed by the Kjeldhal method. These contents, multiplied by the 6.25, were named rumen non-degradable neutral detergent insoluble protein (NDNDIP) and were considered as the observed or real rumen non-degradable protein fraction.

The statistical evaluation was done by the adjustment of a least square straight line regression model with the observed values (NDNDIP) as the independent variable (X) and the predicted values (ADIP) as the dependent variable $(\mathrm{Y})$. The statistical tests involved the null hypotheses: $\mathrm{H}_{0:} \beta_{0}=0$, and $\mathrm{H}_{0 \text { : }} \beta_{1}=1$, being adopted in both cases two-tailed alternative hypotheses. The non-rejection of both null hypotheses $(\alpha=.05)$ indicates similarity between the predicted and observed values, whereas the non-acceptance of one of those implies dissimilarity between such values. During the incubation three samples were disregarded due to the nylon bags rupture.

The descriptive statistics for the ADIP and NDNDIP contents are expressed in Table 1. The discrepancy between the arithmetic means of both concentrations allows, in an initial way, to presuppose that there is a possible non-similarity between the predicted and observed values.
Table 1. Descriptive statistics for the contents (\% of dry matter) of acid detergent insoluble protein (ADIP) and rumen non-degradable neutral detergent insoluble protein (NDNDIP)

\begin{tabular}{lcc}
\hline & \multicolumn{2}{c}{ Variable } \\
\hline Statistic & ADIP & NDNDIP \\
Mean & 0.983 & 1.493 \\
Mode & --- & --- \\
Median & 0.972 & 1.462 \\
Coefficient of variation (\%) & 40.3 & 26.1 \\
Number of observations (n) & 93 & 93 \\
\hline
\end{tabular}

Such assumption is confirmed by the nonacceptance of both initially proposed null hypotheses $(\mathrm{P}<.01)$. The elevated concentration of points below the equality line ( $\mathrm{Y}=\mathrm{X}$, Fig. 1) indicates underestimation of rumen nondegradable protein contents through the ADIP. This fact confirms the tendency previously exhibited by the descriptive inspection of the ADIP and NDNDIP arithmetic means (Table 1).

The dispersion of ordinate pairs (Fig. 1) also indicate a lack of a defined relationship between the ADIP and NDNDIP values, which is confirmed by the low and non-significant $(\mathrm{P}>$.28) Pearson linear correlation $(\mathrm{r}=.1124)$.

Such behaviors evidence the fact that there is not enough empirical data that support the adoption of ADIP as an estimator of the rumen nondegradable protein content in tropical grasses.

According to Van Soest (1994), the use of the acid detergent residue as a digestibility predictor is not based on any solid theoretical assumption, but only on eventual statistic associations, which can be broadly influenced by environmental factors. In a logical assumption, being the ADIP a component of the acid detergent residue, its use as a rumen non-degradable protein estimator would be accepted only by observations without necessarily establishing casual relationships between their components with those inaccessible to the rumen microorganisms.

It should be pointed out that the acid detergent residue can be considered only as a preparatory step towards some cell wall components evaluation, not being considered as a biologically valid concept of dietary fiber (Van Soest et al., 1991; Van Soest, 1994), reinforcing that digestibility predictions based on acid detergent insoluble protein are not adequate. 


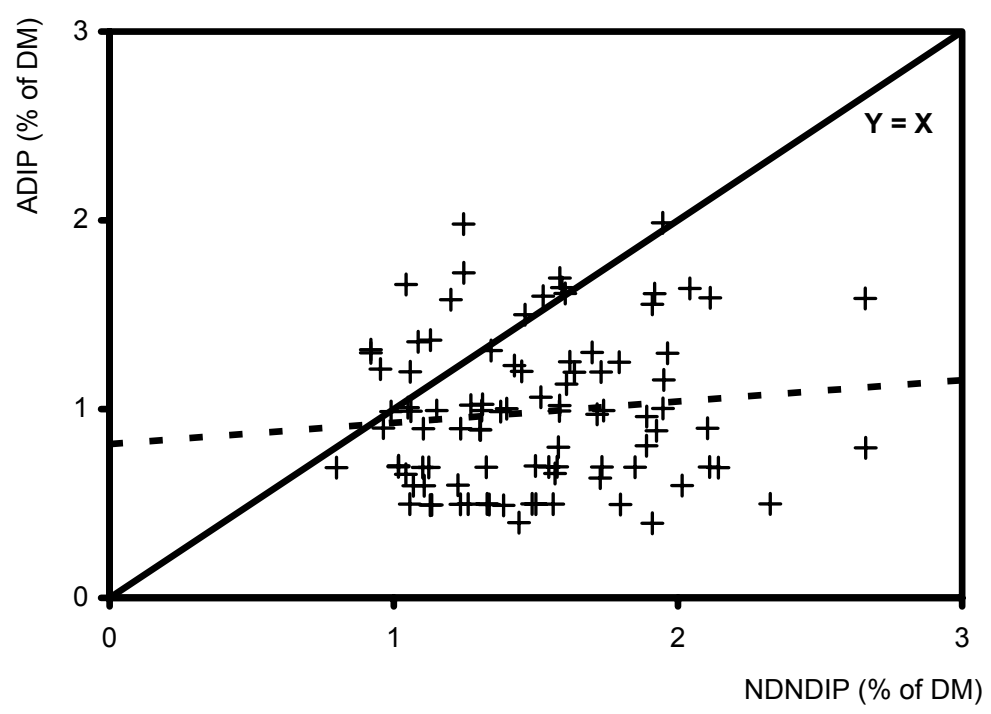

Figure 1. Descriptive behavior for the relationship between the contents of non-degradable neutral detergent insoluble protein (NDNDIP) and acid detergent insoluble protein (ADIP) (the dashed line corresponds to the least squares straight line $\left.-\hat{Y}=0.8145+0.1131 \mathrm{X} ; \mathrm{r}^{2}=.0124\right)$.

The rumen non-degradable protein should be considered, in essence, as a biological concept in which environmental, chemical, physiological and anatomic effects interact to limit the potential microbial access, blocking its degradation. Thus, like the acid detergent residue, the ADIP did not represent a biological concept, but only a chemical approximation of the microbial inaccessibility definition. So, it is impossible to use it as a simple and direct predictor of a biological concept as rumen nondegradable protein, which was subject to all interactions described previously. It is good to point out that the action of the different factors should be considered so that the accuracy of estimates can be reached.

So, in the absence of a predictor model that can consider at least the major factors that influence the rumen non-degradable protein fraction, the estimation by biological methods is suggested. The method used in this study is based on the assumption that the residual protein after 240 of rumen incubation will get near, with great intensity, to the real rumen non-degradable protein fraction, which constitutes an asymptotic concept. The treatment with neutral detergent after the rumen incubation is done only to remove microbial residues adherent to the fiber components (Van Soest, 1994), which could cause an overestimation of the protein residue.

Data from studies with markers shows that the fiber residue concentrations in food resulting from long time rumen incubation are higher with neutral detergent treatment compared to acid detergent treatment (Detmann 2004) ${ }^{1}$. However, in both treatments the residues are considered indigestible. In this way, when the residue of rumen incubation is treated with acid detergent it could be discarding part of the non-degradable nitrogenous compounds soluble in low $\mathrm{pH}$, leading to the underestimation of total nondegradable fraction. Such possibilities justify the treatment with neutral detergent in the posincubation procedures for the non-degradable protein fraction estimation in tropical forages.

Keywords: acid detergent insoluble protein, nitrogenous compounds, rumen degradation

\footnotetext{
${ }^{1}$ Detmann, E. (2004) - UFV - personal communication
} 


\section{RESUMO}

Estimou-se a fração protéica não degradável no rúmen obtida a partir dos compostos nitrogenados insolúveis em detergente ácido (PIDA). Foram utilizadas 96 amostras obtidas por simulação manual de pastejo e extrusa esofágica em dois sistemas de pastejo rotacionado com capim-elefante (Pennisetum purpureum cv. Napier) e com capim-mombaça (Pannicum maximum cv. Mombaça). A fração protéica não degradável no rúmen observada ou real foi obtida por intermédio de incubação ruminal das amostras por 240 horas, seguida de tratamento com detergente neutro, denominada proteína não degradável insolúvel em detergente neutro (PIIDN). A comparação entre valores preditos e observados foi feita por intermédio do ajustamento de equação de regressão linear simples de valores preditos sobre valores observados (PIIDN). Os resultados permitiram evidenciar a não-equivalência $(P<0,01)$ e a não associação $(P>0,28)$ entre os valores preditos e observados da fração protéica não degradável. Sugerese que a PIDA não seja adotada como estimador da fração protéica não degradável, a qual deve ser estimada por intermédio de métodos biológicos, dentre os quais sugerem-se os protocolos adotados para obtenção das concentrações de PIIDN.

Palavras-chave: fração protéica não degradável, compostos nitrogenados, degradação ruminal

\section{REFERENCES}

DETMANN, E.; PAULINO, M.F.; ZERVOUDAKIS, J.T. et al. Evaluation of digestibility of acid detergent insoluble nitrogen in cattle grazing a signal grass pasture. In: WORLD CONFERENCE OF ANIMAL PRODUCTION, 9., 2003, Porto Alegre. Proceedings... Porto Alegre: World Association for Animal Production, 2003. p.39 (whole text in a CD-ROM file).

GOERING, H.K.; VAN SOEST, P.J. Forage fiber analyses (apparatus, reagents, procedures, and some applications). Washington: USA
Department of Agriculture, 1975. 20p. (Agriculture Handbook, No. 379)

SNIFFEN, C.J.; O'CONNOR, J.D.; VAN SOEST, P.J. et al. A net carbohydrate and protein system for evaluating cattle diets: II. Carbohydrate and protein availability. J. Anim. Sci., v.70, p.3562-3577, 1992.

VAN SOEST, P.J. Nutritional ecology of the ruminant. Ithaca: Cornell University, 1994. 476p.

VAN SOEST, P.J.; ROBERTSON, J.B.; LEWIS, B.A. Methods for dietary fiber, and nonstarch polysaccharides in relation to animal nutrition. $J$. Dairy Sci., v.74, p.3583-3597, 1991. 